\title{
Dominasi Medis Modern Atas Medis Tradisional Suku Sumuri, Teluk Bintuni, Papua Barat
}

\author{
Modern Medicine Domination Over Traditional Medicine in \\ Sumuri Ethnic, Bintuni Bay, West Papua
}

\author{
Atik Triratnawati \\ Departemen Antropologi, Fakultas Ilmu Budaya, Universitas Gadjah Mada \\ Jalan Nusantara 1, Bulaksumur, Kabupaten Sleman, Daerah Istimewa Yogyakarta, \\ Telepon: (0274) 513096 \\ e-mail: atik_triratnawati@yahoo.co.id
}

\begin{abstract}
Declaration 1990-2015 MDG's 4 and 5 points in Indonesia fail due to a decrease in maternal and infant mortality rate is not reached until three quarters. Sumuri District, in West Papua is one of the area that maternal and infant mortality rates high, althought free health care for its residents. This paper wants to explore how the interaction between modern medicine and local medicine so the dominant health care in the community will be identified. Ethnographic study by living together with the local community to make the observation of the patient's health centers, community leader interviews, adult population, health workers and mini Focus Group Discussion among 4 mothers who has under 5 years old children conducted in June 2014. Government, oil and gas companies are aggressively introducing modern medical to the residents of Sumuri District, as a result communities have high interest to visit the health center for treatment and natural healing tends to disappear. New health institutions such as health centers, integrated health, midwives, nurses, physicians are able to shift the role of traditional birth attendants, traditional healer or traditional medicine. As a result of social relations within the extended family was replaced by a stronger role of midwives, nurses and doctors. However, the older generation tends to be more suitable with traditional healing compare to modern medicine.
\end{abstract}

Keywords: dominance, modern medicine, natural, patterns of health seeking behavior, Sumuri

\begin{abstract}
Abstrak
Deklarasi MDG's 1990-2015 butir 4 dan 5 di Indonesia dinyatakan gagal akibat penurunan angka kematian ibu dan bayi hingga 3/4 tidak tercapai. Distrik Sumuri, Papau Barat merupakan wilayah dengan angka kematian ibu dan bayi tinggi meskipun pelayanan kesehatan gratis tersedia bagi penduduknya. Tulisan ini mengeksplorasi bagaimana interaksi antara budaya kesehatan yang berasal dari luar (modern) dan budaya lokal sehingga pelayanan kesehatan apa yang dominan di masyarakat akan teridentifikasi. Studi etnografi dengan cara tinggal bersama dengan penduduk setempat untuk melakukan pengamatan terhadap pasien Puskesmas, wawancara tokoh masyarakat, penduduk, petugas kesehatan serta mini Focus Group Discussion terhadap 4 ibu Balita dilakukan Juni 2014. Pemerintah, perusahaan minyak dan gas secara gencar mengenalkan medis modern ke penduduk Distrik Sumuri, akibatnya animo berobat ke Puskesmas tinggi dan penyembuhan alami cenderung hilang. Kelembagaan kesehatan yang baru seperti Puskesmas, Posyandu, dan petugas kesehatan seperti bidan, perawat, dokter mampu menggeser peran dukun bayi, dukun penyembuh maupun praktik pengobatan tradisional. Akibatnya relasi sosial dalam keluarga luas yang dahulu kuat menjadi melemah digantikan oleh peran bidan, perawat dan dokter. Namun, generasi tua cenderung lebih cocok dengan penyembuhan tradisional dibandingkan modern.
\end{abstract}

Kata kunci: alami, dominan, medis modern, pola perilaku pencarian pengobatan, Sumuri

\section{Pendahuluan}

Millineum Development Goal's (MDG's) telah berakhir di tahun 2015. Indonesia sebagai salah satu dari 189 negara yang ikut mendeklarasikan MDG's dianggap gagal akibat banyak butir-butir dari MDG's yang tidak tercapai. Tujuan MDG's butir 4 dan 5 mengenai penurunan kematian bayi atau anak dan peningkatan kesehatan ibu masih jauh dari harapan, walaupun berbagai program penurunan angka kematian telah diterapkan. Penurunan Angka Kematian Ibu (AKI) secara global sebesar 1,3\%, 
sementara Indonesia hanya mampu menurunkan 0,6\% (Kelompok Kerja Kesehatan Ibu dan anak, FK UGM 2015). Akibatnya Indonesia membutuhkan lagi bantuan dana asing guna menuntaskan penurunan AKI dan bayi hinga $3 / 4$ nya.

Provinsi Papua Barat termasuk salah satu wilayah di Indonesia yang masih tertinggal dalam masalah kesehatan khususnya kesehatan ibu dan bayi. Tahun 2012 di Teluk Bintuni misalnya, angka kematian ibu mencapai tujuh orang (BPS 2013). Angka kematian ibu dan bayi tersebut adalah yang tertinggi di Indonesia (Susenas 2012). Salah satu penyebab langsung kematian ibu adalah eklampsia/preeklampsia, perdarahan, sepsis, aborsi dan infeksi (Wilopo 2010). Sedangkan penyebab tidak langsung kematian ibu antara lain keterbatasan akses terhadap layanan kesehatan yang bermutu, buruknya sistem kesehatan, rendahnya perilaku hidup sehat masyarakat (AIPMNH 2013). Banyak kematian yang dapat dicegah jika teridentifikasi dini dan ditangani secara memadai di fasilitas kesehatan. Namun, keterbatasan infrastruktur, sarana transportasi, belum memadainya tenaga kesehatan, kondisi geografis dan serta faktor sosial budaya seperti pengambilan keputusan di keluarga yang lambat menjadi kendala utama masyarakat yang tinggal di pedesaan untuk dirujuk ke fasilitas kesehatan (AIPMNH 2013).

Keterbatasan fasilitas kesehatan dan jumlah tenaga kesehatan menjadi kendala pelayanan kesehatan ibu dan anak. Padahal sumbangan pelayanan kesehatan secara luas mampu meningkatkan angka harapan hidup manusia abad ke-21 (Baum 2008). Distrik Sumuri, Teluk Bintuni, Papua Barat, yang dihuni suku Sumuri, jumlah persalinan oleh bukan tenaga kesehatan (dukun bayi) cenderung terus meningkat dari tahun ke tahun. Hal ini dikarenakan terbatasnya jumlah tenaga kesehatan serta luasnya daerah dan sulitnya medan (letak geografis) termasuk terbatasnya transportasi. Hal itu dapat terlihat dari tabel 1 .

Tabel 1.

Jumlah tenaga kesehatan di Papua Barat Tahun 2011

\begin{tabular}{lcccc}
\hline \multicolumn{1}{c}{ Wilayah } & Dokter & Perawat & Bidan & Apoteker \\
\hline Distrik Sumuri & 1 & 9 & 4 & 0 \\
Kabupaten Teluk Bintuni & 32 & 196 & 80 & 6 \\
\hline
\end{tabular}

Sumber: Kabupaten Teluk Bintuni dalam angka 2012

Distrik Sumuri merupakan salah satu dari 22 distrik di Papua Barat dengan kondisi daerah pantai yang memiliki fasilitas kesehatan yang relatif baik. Akan tetapi persebaran tenaga kesehatan belum merata di semua wilayah. Puskesmas induk Tofoi tenaga kesehatan sudah lengkap meski belum memiliki tenaga apoteker. Akan tetapi di Sumuri persalinan oleh bukan tenaga kesehatan masih tetap tinggi. Hal ini dikarenakan banyak faktor seperti adat kebiasaan, kemudahan dan biaya yang murah.

Tabel 2.

Jumlah kelahiran menurut penolong kelahiran tahun 2011

\begin{tabular}{lcccc}
\hline \multicolumn{1}{c}{ Wilayah } & $\begin{array}{c}\text { Tenaga } \\
\text { kesehatan }\end{array}$ & $\begin{array}{c}\text { Bukan tenaga } \\
\text { kesehatan }\end{array}$ & $\begin{array}{c}\text { Jumlah } \\
\text { persalinan }\end{array}$ & $\begin{array}{c}\text { Prosentase tenaga } \\
\text { kesehatan }\end{array}$ \\
\hline Distrik Sumuri & 51 & 38 & 89 & 57.30 \\
Kabupaten Teluk Bintuni & 932 & 244 & 1176 & 79.25 \\
\hline
\end{tabular}

Sumber: Kabupaten Teluk Bintuni dalam Angka 2012

Dari tabel 1 dan 2 terlihat bahwa jumlah tenaga kesehatan di Papua Barat cukup memadai, akan tetapi persebarannya tidak merata. Distrik Sumuri terlihat persentase tenaga kesehatan masih rendah (57.30\%), sementara seluruh Papua Barat rata-rata sudah mencapai 79.25\%. Jumlah kelahiran tahun 2011 juga terlihat perbedaan angka yang tidak jauh berbeda yaitu 51 ditolong tenaga kesehatan dan 38 oleh bukan tenaga kesehatan. Angka sekitar $40 \%$ penolong persalinan dukun ini menyiratkan masyarakat setempat masih tinggi animonya terhadap dukun dalam persalinan.

Penduduk Papua Barat dalam banyak aspek tertinggal pembangunannya di banding wilayah lain. Terisolirnya wilayah membuat keterbatasan sumber daya manusia menjadi penghambat kemajuan. Dalam bidang kesehatan kematian ibu dan bayi, serta ancaman penyakit malaria masih terjadi di 
Papua Barat (Warip 2000). Distrik Sumuri, tercatat tahun 2013 ada satu kematian ibu, dua kasus kematian bayi serta satu kasus kematian balita. Tahun 2014 terdapat satu kasus kematian ibu melahirkan (Data Puskesmas Tofoi 2013). Angka itu tergolong tinggi untuk ukuran Indonesia. Hal ini menunjukkan bahwa pencegahan kematian ibu, bayi dan balita belum memadai. Kondisi ini menyiratkan masalah kesehatan ibu dan bayi di negara berkembang seperti Indonesia, masih menjadi masalah utama, sebagaimana negara Laos, Cambodia, dan Myanmar (Chongsuvivatwong et al. 2011).

Secara turun temurun masyarakat Papua Barat telah mengenal kearifan lokal bidang kesehatan, seperti penggunaan tumbuhan herbal (alam) untuk mengatasi berbagai penyakit (Sangat \& Zuhud 2000). Bahkan untuk penolong persalinan mereka mengenal adanya dukun beranak yang berasal dari kerabat sendiri seperti ibu, mertua, paman maupun tetangga. Praktik pengobatan tradisional telah berlangsung lama, karena pada masa lalu wilayah Papua Barat belum terjangkau sistem kesehatan modern sehingga pengobatan tradisional yang dominan. Hal ini dikarenakan cara tradisional itulah yang dirasa cocok dan mudah untuk mereka. Masalah yang muncul saat ini adalah di saat sistem medis modern telah diadopsi oleh pemerintah bahkan tenaga bidan/perawat telah ditempatkan di setiap desa/kampung, akankah medis tradisional masih memegang peran di masyarakat? Dari hal itu muncul pertanyaan: mengapa masyarakat lokal menerima sistem medis modern serta bagaimana peran/posisi medis tradisional pada masyarakat Distrik Sumuri? Apakah kedua sistem itu saling melengkapi satu dengan yang lain ataukah yang satu lebih dominan daripada yang lain? Jika ada yang dominan, faktor atau peristiwa apakah yang mengakibatkan hal itu terjadi?

Tulisan ini menganalisis bagaimana pengalaman penduduk Sumuri terkait dengan pelayanan kesehatan modern serta posisi pengobatan tradisional terhadap medis modern. Dengan mengamati kehidupan masyarakat dalam masalah kesehatan dapat diketahui bagaimana interaksi medis modern dan tradisional dalam konteks masyarakat Sumuri yang termasuk kelompok wilayah terisolir dan jauh dari pusat kota Kabupaten Teluk Bintuni ini.

\section{Metode Penelitian}

Penelitian dengan pendekatan kualitatif ini dilakukan Juni 2014 di Distrik Sumuri, khususnya di ibukota distrik yaitu Tofoi. Tofoi berjarak $350 \mathrm{~km}$ dari ibukota Propinsi Papua Barat yaitu Teluk Bintuni. Distrik Sumuri terdiri dari lima kampung: Sumuri, Tofoi, Materabu, Forada dan Tanah Merah. Jumlah kepala keluarga di Tofoi mencapai 535 yang terdiri dari 235 KK penduduk asli dan 300 KK pendatang (Monografi Kampung Tofoi 2013). Distrik Sumuri terdapat banyak aktivitas penambangan minyak, gas, hasil hutan kayu dan perkebunan kelapa sawit sehingga secara ekonomi ada perputaran uang yang cukup besar di wilayah tersebut. Namun demikian, ditemukan $175 \mathrm{KK}$ diantaranya termasuk kriteria keluarga miskin. Jauhnya jarak tempuh dari pusat ibukota mengakibatkan wilayah Sumuri termasuk terisolir sebab hanya ada angkutan sungai berupa kapal ketinting dan kapal feri yang beroperasi pada hari-hari tertentu. Angkutan ini menjadi andalan mobilitas penduduk ke luar wilayah Sumuri.

Proses pengumpulan data dilakukan melalui observasi pada pasien di Puskesmas Induk di Tofoi, praktik bidan swasta, wawancara terhadap ibu Balita, tokoh masyarakat, tokoh adat yang berjumlah 15 orang, serta kelompok kecil Focus Group Discussion (FGD) dengan peserta empat ibu-ibu yang memiliki balita. Ibu-ibu dipilih sebagai peserta FGD karena wanita lebih rentan terhadap penyakit dan kesehatan yang buruk (Burns 2000). FGD penting untuk menggali informasi mengenai konsep, persepsi, ide-ide kelompok menurut pandangan emik (Hardon et al. 1995). Melalui FGD pula maka proses pengumpulan data dan informasi yang sistematis mengenai suatu permasalahan tertentu yang spesifik dapat dilakukan (Irwanto 2006). Wawancara dikhususkan pada ibu yang memiliki balita karena perempuan yang sudah menikah memiliki tanggung jawab pada kesehatan suami dan anak (Ratnawati et al. 2013). 
Masyarakat, Kebudayaan dan Politik Vol. 30, No. 2, tahun 2017, hal 174-187

\section{Hasil Penelitian dan Pembahasan}

\section{Kondisi sosial budaya}

Semenjak bupati Teluk Bintuni pertama dijabat oleh seorang dokter gigi tahun 2004, pelayanan kesehatan di fasilitas kesehatan pemerintah dilakukan secara gratis bagi semua penduduk. Hal ini terkait dengan visi, misi, pemerintah setempat yang ingin meningkatkan dan memajukan sumber daya manusia lewat pendidikan dan kesehatan, sehingga bidang pendidikan dan kesehatan menjadi prioritas utama pembangunan.

Dalam upaya memperbaiki ketertinggalan dalam bidang kesehatan maka program satu kampung satu bidan diterapkan di wilayah Teluk Bintuni. Akan tetapi mengingat luasnya daerah serta keterisolasian wilayah berdampak pada tidak betahnya bidan bertempat tinggal di desa. Masih ditemukan beberapa wilayah kampung yang tidak ada bidannya. Tenaga kesehatan yang dikenal dan diminati masyarakat adalah S (37), pendatang yang telah tinggal 10 tahunan di Tofoi. S meski hanya seorang perawat tetapi semua penduduk Sumuri memanggilnya "bu bidan" karena ia terbiasa melakukan aneka macam pelayanan kesehatan termasuk persalinan. Seperti penuturan $\mathrm{S}$ berikut:

"Saya asli Buton, lulus dari Sekolah Perawat Kesehatan Kendari, menjadi PNS tahun 2008, tetapi saya sudah berada di sini sejak lama sebelum Puskesmas Tofoi berdiri tahun 2004”.

Penduduk Distrik Sumuri yang beretnis Sumuri sejak zaman penjajahan Belanda dan Jepang telah didatangi bangsa asing termasuk pendatang, akibatnya interaksi orang Sumuri dengan orang asing maupun etnis lain sangat kuat. Penduduk Sumuri didominasi oleh pendatang, yang berjumlah lebih dari 50\% (Pitoyo et al. 2007). Sumuri dikenal sebagai wilayah yang potensi ekonominya luar biasa sehingga jumlah pendatang dari etnis lain terus meningkat selain bangsa asing (ekspatriat).

Perubahan sosial ekonomi terus terjadi di Sumuri. Masyarakat yang sebelumnya bekerja sebagai petani, peladang mulai berkembang jenis pekerjaannya setelah ekonomi kapitalis yang dibawa oleh perusahaan asing dan nasional yang bergerak di bidang pertambangan dan perkebunan masuk ke sana. Ditambah lagi pemekaran wilayah dimana Kabupaten Teluk Bintuni berdiri sebagai kabupaten terpisah dari Sorong mengakibatkan wilayah ini semakin terbuka (Rahman et al. 2008). Aspek kehidupan masyarakat baik ekonomi, politik, sosial budaya, kesehatan dan keamanan pun berubah seiring dengan perubahan fungsi wilayahnya.

\section{Folk sector tergeser oleh professional sector}

Dalam kajian Antropologi Kesehatan, sistem kesehatan terdapat variasi tingkat organisasi. Dimulai dari tingkat yang paling rendah, yaitu rumah tangga di mana orang mengelola ide dan aktivitas untuk mengembalikan kesehatannya. Tingkat berikutnya adalah komunitas lokal, kabupaten, nasional dan terakhir internasional. Kekuatan politik dan sumber ekonomi akan meningkatkan kesehatan, meski secara ekstrem kedua hal itu tidak dapat terdistribusi dengan rata (Hardon et al. 1995).

Di Distrik Sumuri terjadi lompatan pemikiran, mereka merupakan komunitas lokal kemudian berubah ke komunitas internasional. Dengan masuknya ekonomi uang yang cepat ditambah introduksi dari perusahaan dan pemerintah atas lembaga kesehatan modern maka perubahan pun terjadi secara cepat. Penduduk seakan-akan dipaksa untuk berubah dan berpindah dari pemikiran medis tradisional ke modern. Layanan dan akses kesehatan, seperti Posyandu, Puskesmas pembantu, Puskesmas induk, klinik perusahaan semakin didekatkan ke masyarakat. Interaksi dengan orang luar, ditambah gaya hidup petugas kesehatan maupun pegawai pemerintah, perusahaan migas dan kelapa sawit yang memanfaatkan pelayanan medis modern mempengaruhi cara hidup masyarakat lokal. Mereka mulai percaya terhadap medis modern dan kemudian mengadopsinya dalam kehidupan sehari-hari. Akibatnya proses layanan kesehatan dari tingkat rumah tangga mulai hilang digantikan oleh layanan kesehatan tingkat dasar, yaitu Puskesmas. 
Explanatory models yang dikemukakan oleh Kleinman (Kleinman 1988; Hardon et al. 1995) menjelaskan tentang tumpang tindihnya ide-ide kesehatan dan praktiknya dalam suatu budaya. Sektor pelayanan kesehatan, seperti sektor folk (rakyat, di mana mereka terdiri dari penyembuh lokal, seperti: ahli jamu, patah tulang, dukun bayi, dukun spiritual), sektor populer (orang awam, nonprofesional ) dan sektor profesional (dokter, paramedik) saling berperan di masyarakat. Masingmasing sektor pelayanan kesehatan ini memiliki keunggulan dan kelemahan dan mereka dapat saling berkonflik untuk mendapatkan pengaruh di masyarakat.

Pada kondisi sosial ekonomi masyarakat Sumuri sekarang ini yang terus membaik, explanatory models dapat dipakai untuk menjelaskan fenomena pelayanan kesehatan yang ada. Masyarakat Sumuri sedang mengalami perubahan, sehingga ketiga sektor pelayanan kesehatan ini saling bersaing, meski nanti akan terlihat mana yang paling dominan. Antara praktik dukun bayi dan kerabat yang terbiasa menolong persalinan dengan peran bidan dan dokter, masing-masing berusaha menarik hati penggunanya. Dukun bayi dan kerabat dengan praktik pelayanan di rumah pasien adalah bagian dari sistem kesehatan tradisional. Di sisi lain ada bidan, perawat, dokter dan Puskesmas dengan layanan kesehatan yang mengambil tempat di gedung milik pemerintah atau milik pribadi mewakili praktik medis modern. Masing-masing pihak ini memiliki konsep, struktur dan metode terapi yang berbeda, sehingga apabila seseorang dari medis tradisional berubah ke medis modern maka perubahan akan terjadi tidak hanya dalam tataran pemikiran melainkan juga relasi sosial yang ada.

Ada alasan kuat mengapa ibu-ibu generasi tua di Sumuri lebih menyukai bersalin ke dukun bayi daripada bidan. Kedekatan hubungan mereka dengan dukun bayi hampir tanpa jarak karena mereka memiliki persamaan budaya. Sementara itu bidan tetap dianggap sebagai orang luar, baik karena asalnya memang dari luar Sumuri maupun adanya perbedaan dasar dalam praktik pelayanan biomedis mereka. Persamaan bahasa sehari-hari antara pasien dan dukun bayi juga menjadi ikatan yang kuat di antara mereka (Alesich 2008). Secara budaya pun pengaruh relasi kuasa antara dukun terhadap pasien masih kuat, dukun merupakan orang tua yang sangat dihormati di masyarakat, sehingga setiap perkataan dan nasihat dukun pun dituruti pasiennya.

Semasa wilayah Teluk Bintuni masih menjadi bagian dari Kabupaten Sorong, penduduk Sumuri dalam mendapatkan pelayanan kesehatan mereka harus ke wilayah Babo yang berjarak sekitar 150 $\mathrm{km}$. Pada saat itu folk sector mendominasi, sebab pelayanan kesehatan di wilayah Sumuri belum terjangkau oleh bidang medis modern. Menurut penuturan tetua adat KS (58 tahun) pada masa lalu semua orang jika ingin berobat ke medis modern harus menempuh perjalanan jauh untuk sampai ke Babo. Masyarakat saat itu lebih mempercayai penyembuhan alami lewat herbal. Apabila ada seseorang yang menderita penyakit malaria maka cukup diberi daun maupun akar-akaran yang mereka cari di hutan. Pada saat itu jumlah penyakit belum sebanyak sekarang, yang paling dominan adalah malaria. Penyembuhan malaria lewat daun pepaya, penurun panas dengan kompres daun jarak atau daun belakang babiji, serta pengobatan diare dengan daun jambu maupun lelah dan capai yang diobati dengan daun gatal masih diingat dengan baik oleh kelompok generasi tua. Kebiasaan generasi tua menggunakan pengobatan alami secara logika memang benar. Sebab dalam obat alami terkandung senyawa-senyawa yang masih lengkap. Senyawa itu akan bereaksi secara perlahan dengan tubuh dan berinteraksi lebih ramah dengan organ-organ tubuh. Oleh karena itu, jika seseorang proaktif mengobati dengan obat alami, untuk jangka waktu yang panjang kesehatannya akan jauh lebih baik (Kerthyasa \& Yuliati 2013).

Dahulu, hutan di wilayah Sumuri masih menyediakan aneka ragam tumbuhan untuk pengobatan. Bahkan setiap orang pada saat itu hafal akan khasiat tanaman obat beserta cara mencari tanaman itu di hutan. Penggunaan sistem medis tradisional (etnomedisin) sangat kuat (Foster dan Anderson 1990). Namun, sekarang ini seiring dengan pembukaan lahan hutan baik untuk penambangan maupun perkebunan kelapa sawit, vegetasi tanaman obat ikut hilang. Ditambah lagi kelompok usia tua yang hafal dengan aneka tanaman obat saat ini sudah enggan ke hutan akibat sulitnya mencari tanaman obat. Saat inipun tidak ada lagi anak muda yang mau bekerja di hutan apalagi mencari tanaman berkhasiat obat. Akibatnya mereka cenderung mencari cara termudah, yaitu jika sakit pergi ke Puskesmas. 
Dalam interaksi antar etnis di Sumuri terlihat jelas bahwa masing-masing etnis berusaha mempertahankan sistem medis sendiri. Etnis Bugis Makassar, Jawa, Kupang, Sunda, masing-masing memiliki dukun bayi yang berasal dari etnisnya. Yang menarik, orang Sumuri tidak fanatik harus mencari pertolongan dukun dari kelompoknya, melainkan mereka juga memanfaatkan dukun bayi dari etnis lain. Toleransi dan saling bantu antar etnis dan golongan agama masih kuat di wilayah ini. Dengan kondisi seperti itu dapat digambarkan bahwa pluralisme medis di Sumuri cukup kuat, karena selain medis modern diterima penduduk lokal juga masing-masing sistem medis lokal mampu hidup di tengah berbagai sistem medis yang ada (Hardon et al. 1995). Folk medicine dan pelayanan sektor rakyat seperti dukun bayi, dukun ahli tulang, dukun suanggi (roh halus) tetap memainkan peran utama dalam mengobati penyakit penduduk. Mereka juga mengandalkan tanaman obat (herbal, bahan alami) untuk menyembuhkan aneka penyakit. Ketergantungan masyarakat pada dukun bayi dan dukun suanggi cukup tinggi baik untuk menolong persalinan maupun penyakit dan kondisi kesehatan lainnya.

Sejak tahun 2004, dokter dan petugas kesehatan dengan gencar mensosialisasikan sistem medis modern sehingga kemudian muncul kecenderungan semua persalinan dilakukan di fasilitas kesehatan baik itu Puskesmas Pembantu, Puskesmas maupun rumah sakit. Kontak masyarakat setempat dengan medis modern terjadi bukan hanya lewat kunjungan mantri pada masa lalu, ditambah pendirian Puskesmas di wilayah Distrik Sumuri, akan tetapi pada saat yang bersamaan peran perusahaan penambangan cukup kuat dalam mengenalkan medis modern ke masyarakat. Perusahaan dengan aktif melakukan pemberdayaan masyarakat bidang kesehatan, sehingga muncul kesadaran masyarakat akan pentingnya kesehatan. Lembaga kesehatan serta pemanfaatan klinik perusahaan yang melayani pelayanan kesehatan bagi pegawainya baik yang berasal dari pendatang maupun penduduk lokal semakin meningkat.

Fasilitas kesehatan modern merupakan hal yang baru mengingat bahwa tenaga kesehatan tidak tersedia di tiap kampung, terlebih lagi kampung yang jauh dan terisolir dari jangkauan akses transportasi. Oleh karena itu mengenalkan sesuatu yang baru di tengah tradisi setempat di mana persalinan dilakukan oleh dukun menjadi tantangan tersendiri bagi petugas kesehatan. Masuknya sistem medis modern di Sumuri mengubah perilaku masyarakat dalam bidang kesehatan. Perubahan kebiasaan bersalin dari di rumah kemudian berpindah ke fasilitas kesehatan, bukan hal yang mudah dilakukan. Hal ini mengingat kebiasaan bersalin di rumah dengan ditolong dukun telah menjadi tradisi turun temurun bagi semua perempuan hamil di wilayah tersebut. Pada saat persalinan di rumah, maka yang diperbolehkan hadir hanyalah mereka yang termasuk dalam lingkar kerabat dekat seperti: ibu, mertua perempuan, paman, yaitu mereka yang telah dianggap keluarga senior dan mampu menolong persalinan. Anggota keluarga lain dan tetangga hanya diperbolehkan menunggu di luar ruangan. Kemampuan menolong persalinan dari kerabat itu hanya memotong tali pusat bayi dengan menggunakan bambu dan kemudian diganti dengan silet atau gunting. Sementara itu perawatan selanjutnya pasca persalinan kerabat akan menyerahkannya kepada dukun bayi. Pola kepercayaan pada dukun yang masih kuat ditambah kenyamanan melahirkan di rumah yang telah diturunkan dari generasi satu ke generasi berikutnya, membuat mereka tidak mudah untuk bersalin ke fasilitas kesehatan modern.

Kondisi wilayah perkampungan Tofoi yang terletak di pinggir teluk, dikelilingi perairan, rawa-rawa sangat potensial menjadi tempat berkembangnya nyamuk malaria. Pengobatan malaria $80,90 \%$ dengan meminta jasa tenaga kesehatan, sisanya diobati sendiri $(13,70 \%)$ atau dibiarkan saja $(5,40 \%)$ (Pitoyo et al. 2007). Kondisi ini menyiratkan bahwa pengobatan tradisional khususnya dalam penanggulangan malaria telah mulai memudar dan digantikan oleh sistem medis modern.

Dalam masalah kesehatan ibu dan anak, masih banyak perempuan yang kekurangan gizi serta usia pernikahan muda dengan jumlah paritas yang tinggi. Bahkan 5,50\% perempuan melahirkan anak lebih dari 10 bayi. Alat kontrasepsi dari perempuan berstatus kawin di Sumuri 78,30\% di antaranya memilih tidak menggunakannya (Pitoyo et al. 2007). Tidak mengherankan apabila masalah kesehatan ibu dan bayi masih belum baik mengingat kondisi sosial budaya maupun geografis masyarakat setempat. 
Sampai saat inipun masih ditemukan ibu hamil yang tidak pernah memeriksakan kehamilannya karena merasa kondisi kesehatannya baik-baik saja, sehingga sampai saat melahirkan dengan pertolongan dukun pun tidak ada satu petugas kesehatan yang mengetahuinya. Seperti dikemukakan oleh Y (30 tahun, ibu tujuh anak) partisipan FGD ibu Balita yang menyatakan bahwa dulu ia tidak melakukan perawatan persalinan, tetapi ia hanya pergi ke dukun bayi saat usia kehamilan tiga bulan di mana ia sering merasakan tempat kencingnya turun. Setelah dipijat, maka badan langsung terasa enak. Namun sekarang, ia ke bidan untuk memeriksa kehamilannya karena alasan gratis. Alasan lainnya karena sesama ibu hamil di sana juga periksa kehamilan ke bidan Puskesmas, sehingga ia tergerak melakukannya. Anak-anaknya semua dilahirkan di rumah, dengan ditolong oleh mamanya (ibu dari Y) yang memang terbiasa menolong persalinan. Hanya anak nomor enam dan tujuh yang ditolong bidan. Y menyatakan bahwa semua perempuan yang berusia tua mampu menolong persalinan, dalam arti memotong tali pusat. Mereka memotong tali pusat menggunakan silet dan benang untuk mengikatnya. Bagi para ibu di Sumuri termasuk Y melahirkan di rumah adalah merupakan pilihan terbaik, sebab mereka tidak perlu keluar rumah, sehingga anak-anak tidak perlu ditinggal di rumah sendirian. Mereka juga menyatakan dukun bayi itu masih merupakan orang tuanya sendiri, kerabat, atau tetangga, sehingga tidak perlu dibayar jasanya. Jika dukun bayi itu tetangga atau memang berprofesi sebagai dukun bayi maka mereka cukup membayar dengan sirih pinang seharga Rp.50.000. Nilai uang Rp.50.000 tersebut tergolong murah untuk ukuran masyarakat Sumuri.

Tekad Dinkes agar pelayanan kesehatan mampu menjangkau ke wilayah terisolir sekalipun mendorong petugas kesehatan untuk terus menerus mensosialisasikan program kesehatan ke masyarakat. Pengetahuan, pemahaman dan pentingnya pemeriksaan kesehatan bagi ibu hamil, serta pola perilaku hidup sehat diajarkan bagi semua warga. Animo warga khususnya ibu hamil untuk melakukan pemeriksaan kesehatan ke fasilitas kesehatan pun meningkat. Ibu-ibu hamil rajin melakukan ANC ke Posyandu/Puskesmas. Pemeriksaan kehamilan mulai trimester pertama sampai ketiga mampu dilakukan oleh ibu-ibu hamil saat ini. Akan tetapi, pola pemikiran lama yang masih kuat bercokol di lingkungan masyarakat menyebabkan mereka pun tidak dapat dilepaskan dari pengaruh dukun bayi. Semua ibu hamil meski telah melakukan ANC ke bidan akan tetapi jika kehamilan memasuki usia delapan bulan mereka akan pergi ke dukun bayi untuk pijat. Pijat bagi ibu hamil dimaksudkan agar bayi dalam perut ibu ditata oleh dukun sehingga posisinya normal dan siap untuk dilahirkan. Penduduk setempat mengistilahkan dengan kata "dukun kasih lurus bayi". Ini artinya letak bayi dibetulkan agar siap untuk keluar dari perut ibu dengan posisi yang lurus (normal).

Dari hasil FGD, ibu-ibu muda yang memiliki pengalaman merantau atau sekolah di luar Distrik Sumuri, di mana tingkat pendidikan mereka relatif memadai (SMU ke atas) pelayanan kesehatan modern baik saat pemeriksaan kehamilan maupun persalinan cenderung mereka pilih. Mereka melahirkan anak pertamanya di fasilitas kesehatan. Sementara pada kelompok ibu yang usianya lebih tua, dengan jumlah anak lebih dari dua mereka cenderung memilih bersalin di rumah baik ditolong bidan maupun dukun atau bidan dan dukun bersama-sama.

\section{Pelayanan kesehatan gratis}

Sejak berdirinya Kabupaten Teluk Bintuni, pemerintah daerah menfokuskan pada program kesehatan dan pendidikan lewat pembebasan biaya pelayanan kesehatan dan pendidikan dari SD sampai SMU. Pemda setempat menyadari bahwa untuk mengejar ketertinggalan dalam pembangunan dibanding kabupaten tetangga, maka program kesehatan dan pendidikan terus digalakkan demi peningkatan sumber daya manusia. Pelayanan kesehatan gratis ini disambut baik oleh masyarakat pada umumnya sebab dengan cara ini masalah kesehatan yang mereka alami dicarikan solusinya oleh Pemda. Meski jumlah fasilitas kesehatan, seperti Pustu, Puskesmas terus ditambah dan dilengkapi fasilitasnya, akan tetapi belum semua warga masyarakat terbiasa dengan pola pengobatan medis modern.

Upaya peningkatan kesehatan khususnya ibu dan anak dilakukan dengan berbagai program. Salah satunya melalui promosi kesehatan. Promosi kesehatan dilakukan oleh bidan dan perawat Puskesmas di wilayah kerjanya. Mereka memanfaatkan acara hari besar nasional maupun forum acara-acara keagamaan, seperti pengajian dan kegiatan gereja untuk mengenalkan ke masyarakat mengenai 
pentingnya memperhatikan masalah kesehatan dan penggunaan fasilitas kesehatan pemerintah bagi semua penduduk. Dengan pembebasan biaya pemeriksaan di fasilitas kesehatan milik pemerintah maka diharapkan derajat kesehatan masyarakat akan meningkat, sebab semua gangguan kesehatan akan ditangani di fasilitas kesehatan tersebut.

Promosi kesehatan dilakukan secara komprehensif tidak saja menyangkut program KIA melainkan termasuk pula program PHBS (Perilaku Hidup Bersih dan Sehat) serta perbaikan gizi. Kehidupan masyarakat Papua yang komunal menjadikan program PHBS yang lebih bersifat individual perlu dikenalkan secara benar kepada masyarakat. Telah menjadi kebiasaan lama warga masyarakat bahwa sebelum dan setelah makan/minum mereka tidak pernah cuci tangan. Kemudian sebelum tidur cuci kaki dan sikat gigi dikenalkan di lingkungan warga desa. Dahulu kaum ibu jika akan memegang bayi maupun menyusui langsung dilakukan begitu saja, maka sekarang mereka dikenalkan kebiasaan baru, yaitu cuci tangan saat akan memegang bayi maupun menyusui. Cuci tangan yang disarankan adalah memakai sabun yang mampu membunuh kuman.

\section{Dominasi medis modern atas medis tradisional}

Semenjak medis modern dikenalkan ke masyarakat Sumuri lewat berbagai cara maka lambat laun ketergantungan masyarakat pada pelayanan kesehatan modern semakin kuat. Ada berbagai faktor yang mengakibatkan pelayanan medis modern atau sektor profesional menjadi dominan di masyarakat, antara lain:

\section{Peran pemerintah}

Pemerintah pusat maupun daerah sangat berkepentingan dengan upaya peningkatan kesehatan masyarakat di Kabupaten Teluk Bintuni. Mengingat program kesehatan masih bersifat top-down maka program-program kesehatan yang ada di Indonesia akan diterapkan di semua wilayah negara secara seragam. Salah satu upaya untuk menurunkan angka kematian ibu dan bayi adalah kemitraan ibu bidan dan dukun bayi. Dukun bayi tidak diperbolehkan lagi menolong persalinan, sehingga semua persalinan harus ditolong di fasilitas kesehatan (Poskesdes, Puskesmas). Bahkan untuk menekan angka kematian ibu dan bayi pemerintah juga meluncurkan program rumah tunggu, yaitu layanan kesehatan bagi masyarakat di daerah yang sulit terjangkau dengan mendekatkan pasien kepada fasilitas kesehatan. Ibu hamil diupayakan harus sudah berada di dekat fasilitas kesehatan beberapa hari sebelum bersalin. Tempat tinggal sementara sebelum persalinan tiba baik yang berada di dekat fasiltas kesehatan dasar atau rujukan inilah yang disebut rumah tunggu (AIPMNH 2013:1). Di wilayah Papau Barat rumah tunggu belum merata ada di setiap Puskesmas akan tetapi baru terdapat di Teluk Bintuni dan Distrik Babo saja. Keberadaan rumah tunggu diharapakan mampu menanggulangi akses yang jauh dengan fasilitas kesehatan terdekat. Rumah tunggu memungkinkan keluarga besar tetap bersama si ibu meski bukan di rumah mereka melainkan berada di dekat fasilitas kesehatan sebelum hari persalinan tiba. Dengan demikian pertolongan dini apabila ibu hamil mendapatkan penyulit persalinan dapat diatasi karena ibu hamil sudah berada di dekat fasilitas kesehatan terdekat.

Pemerintah dengan gencar mensosialisasikan program-program kesehatannya melalui banyak jalur. Di Kabupaten Teluk Bintuni sosialisasi itu sampai ke tingkat bawah lewat keberadaan bidan yang terdapat di tiap desa (kampung). Dengan cara ini bidan menjadi kepanjangan tangan pemerintah untuk mensosialisasikan medis modern di tengah-tengah masyarakat desa. Puskesmas induk di Tofoi dengan tenaga medis dan nonmedis berjumlah 16 orang cukup dikenal oleh masyarakat Sumuri. Tenaga medis dari penduduk lokal bercampur dengan pendatang khususnya dari Sulawesi Selatan dan Maluku. Tenaga medis lokal ini mampu menjadi daya tarik penduduk setempat untuk berobat ke Puskesmas. Seperti di Pegunungan Jayawijaya, setelah masyarakat tahu ada tenaga medis yang orang asli Jayawijaya, masyarakat setempat pun tertarik datang ke balai kesehatan untuk mengobati berbagai penyakit yang mereka derita. Padahal, sebelumnya sebagian dari mereka lebih suka pergi ke dukundukun adat (Yuniarti \& Verdiansyah 2007). Di Papua penduduk lebih suka menyampaikan berbagai keluhan penyakitnya kepada tenaga medis yang asli Papua. Kesamaan etnis dan lingkungan budaya menjadikan mereka merasa sama dalam alam berpikirnya. 


\section{Peran Perusahaan}

Beberapa perusahaan besar baik minyak, gas, kayu, maupun kelapa sawit telah berdiri di wilayah Sumuri sejak puluhan tahun lalu. Perusahaan tersebut kebanyakan dikelola pihak asing maupun swasta sehingga masalah kesehatan bagi karyawannya menjadi perhatian perusahaan. Banyak perusahaan memiliki klinik maupun tim medis sendiri, sisanya memiliki kerja sama dengan Puskesmas setempat sehingga apabila ada karyawan yang menderita sakit maka pertolongan dokter segera didapat. Klinik perusahaan terlebih lagi yang mempekerjakan pekerja asing tentu memiliki SOP (Standard Operasional Procedure) yang ketat dalam pelayanan kesehatan bagi karyawannya. Mereka memiliki klinik kesehatan, lengkap dengan dokter, peralatan dan obat-obatan serta jaringan laboratorium maupun alat transportasi yang memadai untuk mengangkut pasien ke pelayanan kesehatan yang lebih lengkap seperti ke Teluk Bintuni, Sorong atau Manokwari. Sementara itu perusahaan kelapa sawit milik pengusaha Malaysia memilih bekerja sama dengan Puskesmas setempat untuk melayani kesehatan para karyawannya. Puskesmas nantinya akan mengenakan tarif pasien umum bagi pegawai perusahaan kelapa sawit.

\section{Peningkatan ekonomi masyarakat}

Masuknya perusahaan-perusahaan baik pertambangan, kayu maupun kelapa sawit berdampak pada ekonomi penduduk setempat. Ekonomi rakyat bertumbuh lewat tenaga kerja lokal yang bekerja di perusahaan tersebut. Uang ganti rugi tanah, sewa tanah maupun uang kerahiman lainnya banyak diterima penduduk lokal. Secara tidak langsung ekonomi rakyat terkena imbasnya. Hal ini juga berdampak pada perputaran ekonomi yang cepat. Peran pendatang dalam menyumbang pertumbuhan ekonomi masih lebih dominan dibanding penduduk lokal, namun gaya hidup kota yang konsumtif telah melanda penduduk lokal. Banyak ibu-ibu Balita yang mengganti ASI dengan susu formula dengan alasan ASI nya tidak keluar atau ASI hanya diberikan selama 1 minggu atau 4 minggu saja. Hasil observasi pada hari Minggu awal Juni 2014 tiga ibu muda yang akan pergi ke Babo dengan naik kapal ketiting semuanya membawa botol susu, susu bubuk dan termos air panas. Saat ditanyakan mengapa bayinya hanya diberi susu botol, ketiganya serentak menjawab karena ASI nya kering, macet (tidak keluar lagi). Ketiga ibu muda dengan anak pertamanya tersebut masing-masing membawa tas yang cukup besar. Tas itu berisi termos besar, kecil, susu bubuk, botol air mineral, tisu basah merek terkenal serta popok bayi sambil tidak lupa membawa sirih pinang. Ibu-ibu muda tersebut menyatakan bahwa bayi mereka mengkonsumsi susu skim buatan pabrik susu dari Yogyakarta sejak ASI mereka terhenti. Kondisi ini sedikit mengherankan mengingat ketiga ibu muda tersebut terlihat sehat, kuat dan tidak ada yang bekerja di luar rumah. Ketiganya adalah ibu rumah tangga.

Harga barang-barang di Tofoi tidak semahal harga barang di wilayah pegunungan, seperti Jayawijaya. Peran iklan dari tv ditambah interaksi penduduk lokal dengan pendatang mengakibatkan kiblat mereka dalam hal konsumsi sangat ke kota. Seorang ibu Balita bahkan mengkhususnya membeli air mineral sulingan yang bermerk tertentu dan berharga mahal demi menjamin kebersihan air susu formula bagi bayinya. Ia pun memesan khusus air mineral itu dari Teluk Bintuni dan menitipkannya pada seseorang dengan imbalan sejumlah uang. Gaya hidup kota menjadi fenomena baru di Tofoi (Sumuri) baik konsumsi sehari-hari maupun perilaku kesehatan yang mengarah pelayanan kesehatan modern.

\section{Perubahan vegetasi hutan}

Perubahan vegetasi hutan akibat pengeboran migas dan dibukanya perkebunan kelapa sawit. Masuknya pendatang maupun penetrasi perusahaan asing di Sumuri tidak hanya berdampak pada pola hidup masyarakat setempat melainkan juga berdampak luas pada kerusakan alamnya. Eksploitasi alam secara besar-besaran untuk memburu hasil alam menimbulkan masalah bagi penduduk lokal. Tanah adat setempat kemudian dikuasai oleh perusahaan baik lewat jalur pemerintah maupun adat. Pelepasan tanah adat ke tangan pengusaha asing, otomatis melenyapkan vegetasi yang ada di tanah adat. Banyak tanaman hutan yang berfungsi sebagai tanaman obat seperti kulit kayu untuk penyembuhan malaria mulai sulit didapat. Jika dahulu mencari tanaman obat sangat mudah, akan tetapi sekarang harus masuk ke hutan yang jaraknya cukup jauh. Tamanan obat yang ada di hutan 
telah berubah menjadi ladang pengeboran minyak. Hilangnya vegetasi hutan dengan demikian menyurutkan warga masyarakat untuk memanfaatkan tanaman obat karena semakin sulitnya mendapatkan bahan tanaman obat tersebut. Sebaliknya hilangnya vegetasi hutan dalam waktu yang sama menghilangkan pengetahuan lokal akan tanaman obat tersebut. Generasi muda tidak mampu lagi mengingat nama tanaman beserta khasiatnya sebab apabila mereka sakit medis modern lah yang akan dipilih sebagai pengobatan pertama. Generasi tua seperti kepala suku Distrik Forada meski masih hafal dengan aneka tumbuhan lokal untuk pengobatan pelbagai penyakit, akan tetapi mereka mulai meninggalkan tanaman alami, dengan alasan Puskesmas lebih dekat aksesnya daripada masuk ke hutan untuk mencari tanaman hutan. Tanaman obat yang bersifat alami mulai hilang dari pengetahuan lokal mereka. Pengetahuan lokal digantikan oleh pengetahuan masa kini yang mengarah pada penyembuhan yang instan atau berbasis medis modern.

\section{Masuknya pendatang}

Dari sejarah masuknya penjelajah dari Eropa, Amerika yang kemudian berkembang menjadi penjajahan dengan mengeksplorasi sumber daya alam Papua perubahan terjadi dalam segala aspek kehidupan. Banyaknya pendatang yang berbeda peradaban berdampak akses penduduk lokal yang sebelumnya terikat dengan tanah mulai tercerabut. Konflik dalam pemanfaatan sumber daya alam pun mulai mengemuka (Yuniarti \& Verdiansyah 2007). Masuknya para pendatang juga memiliki aspek positif dalam bidang kesehatan. Medis modern yang dibawa oleh para pendatang selain agen perubahan lain, yaitu pemerintah dan perusahaan, mereka pun cepat mengadopsinya. Medical pluralism atau pluralisme medis di mana medis modern diterima masyarakat lokal serta interaksi tetap ada diantara mereka (McElroy \& Townsend 1999) di masyarakat cukup kuat sebab antara medis modern dan tradisional saling melengkapi dan tidak menimbulkan konflik terbuka diantara keduanya. Ada rasa saling menghormati di antara medis modern dan tradisional termasuk para pelakunya, yaitu dokter/paramedik maupun dukun setempat.

Kuatnya pluralisme medik juga terlihat dari interaksi yang kuat antara pengguna medis modern dan tradisional. Penduduk Tofoi yang lebih beragam etniknya, masing-masing membawa sistem medisnya sendiri di tempat baru. Dukun bayi dari Jawa, Sunda, Bali, Bugis, Ambon, NTT, Sumuri masingmasing tetap melayani kebutuhan ibu hamil untuk pelayanan ANC maupun persalinan dari warga setempat. Bahkan tidak jarang justru dukun bayi dari Bugis memiliki banyak pasien dari perempuan Sumuri. Dukun Bugis yang memberi pelayanan kesehatan tradisional secara agama Islam tidak menghalangi perempuan hamil dari Sumuri yang beragama Kristen untuk meminta pertolongannya. Sekat-sekat agama tidak lagi menjadi hal yang mendasar, sebab bagi mereka agama apapun itu baik, dan mereka terbiasa hidup rukun diantara umat beragama. Bagi mereka yang paling utama adalah pertolongan yang diberikan oleh penyembuh tradisional itu membawa hasil yang sesuai dengan harapan, caranya mudah, murah serta penyembuhannya manjur.

\section{Keberadaan Puskesmas}

Bangunan puskesmas yang didirikan di Tofoi merupakan sebuah bangunan yang berada tepat di tengah-tengah pemukiman padat di Kampung Baru, Tofoi. Keberadaan Puskesmas induk telah mampu mengubah pola hidup penduduk khususnya terkait dengan PHBS dan mengikis kepercayaan setempat terkait kesehatan dan religi. Meskipun animo masyarakat cukup besar untuk menggunakan pelayanan kesehatan di Puskesmas, namun Puskesmas tidak luput dari berbagai stigma yang melekat pada bangunan maupun personilnya. Pengalaman yang dialami seorang ibu hamil saat bersalin di Puskesmas induk di Tofoi, khususnya yang berakhir dengan kematian, menjadikan pengalaman traumatis bagi ibu hamil lainnya. Kasus yang terjadi beberapa tahun lalu saat seorang Ibu K, asli Ambon, suami asli Sumuri, bersalin anak pertamanya di Puskesmas induk, akan tetapi ternyata ada penyulit persalinan karena bayi dalam kondisi terjepit, sehingga bayi sulit keluar dari rahim ibu. Bayi lahir dalam kondisi meninggal. Pada kehamilan kedua, si ibu mengalami kejadian yang terulang kembali. Saat berada di Puskesmas untuk bersalin, si ibu justru kerasukan roh/setan. Ia menjatuhkan tubuhnya ke sana ke mari akibat sakit yang dirasakannya. Saat persalinan, bayi sulit untuk keluar, tetapi akhirnya bayi dapat keluar meski dalam kondisi meninggal dengan tambahan luka di kening si bayi akibat benturan ibu saat kerasukan roh. Ibu tersebut mengalami perdarahan hebat, kemudian 
dirujuk ke rumah sakit daerah Teluk Bintuni, dan berlanjut lagi ke rumah sakit daerah di Sorong. Akan tetapi nasib ibu tersebut naas, karena ia meninggal dunia di Sorong. Peristiwa dari kasus itu beredar luas di masyarakat. Ibu-ibu hamil kemudian mengalami trauma atas kejadian tersebut. Banyak ibu hamil tidak berani lagi bersalin di Puskesmas induk yang dikatakan angker. Kamar bawah (gedung Puskesmas terletak di tanah atas dan bawah) tempat di mana ruang bersalin dan ruang rawat inap berada menjadi momok bagi penduduk setempat karena ada roh orang mati yang sewaktu-waktu dapat merasuki penghuni kamar bersalin tersebut. Stigma bahwa Puskesmas khususnya kamar bawah yang angker terbawa sampai sekarang dan berpengaruh kuat pada pemahaman ibu-ibu hamil akan kebenaran peristiwa tersebut. Ketakutan akan kerasukan roh apabila bersalin di Puskesmas mengakibatkan pilihan bersalin di rumah menjadi alternatif yang menarik untuk dipilih. Hal ini didukung oleh kebiasaan masyarakat setempat di mana banyak anggota kerabat yang mampu menolong persalinan kerabatnya sendiri. Kemampuan menolong persalinan kerabat sendiri itu diterima secara turun menurun. Kemampuan mereka menolong persalinan sampai pada tahap membatu proses melahirkan sampai ke memotong tali pusat saja. Proses selanjutnya seperti "meluruskan perut" atau pijat oleh dukun pasca persalinan mereka serahkan kepada dukun bayi yang ada di kampung.

Kasus lain Ibu F (25 tahun) melahirkan anak pertamanya di rumah meski ia rutin periksa kehamilannya ke Puskesmas induk di Tofoi. Persalinan ditolong oleh bidan, dukun dan dokter sekaligus. Dokter hanya melakukan pemeriksaan kesehatan untuk memastikan bahwa ibu dan bayinya dalam kondisi sehat dan kemudian menimbang bayinya. Sementara itu selama ia merasakan sakit di rumah dalam waktu enam hari, dukun bayi pun tetap diundang pula. Dukun berfungsi memberikan kekuatan lewat pemberian air dan mantra, sementara bidan adalah yang menolong persalinannya. Ibu F memilih bersalin di rumah karena ia mengalami trauma dengan Puskesmas Tofoi. Meski kematian ayah $\mathrm{F}$ bagi masyarakat Sumuri dipercaya bukan akibat penyebab medis melainkan karena suanggi (lewat mahluk halus akibat diguna-guna orang) tetapi ia tetap takut pada Puskesmas. Praktik suanggi telah dilarang gereja Kristen karena bertentangan dengan ajaran agama, akan tetapi kepercayaan itu tetap hidup di masyarakat (Rahman et al. 2008). Puskesmas bagi masyarakat Sumuri bernilai ganda yaitu sebagai tempat yang angker tetapi sekaligus menjadi tujuan utama pertolongan pertama jika ada yang sakit.

\section{Pengaruh sistem medis modern dan hilangnya relasi sosial}

Apabila pada masa lalu peran dukun bayi dalam proses persalinan memegang peran sentral, maka yang terjadi saat ini adalah kemitraan dukun dan bidan. Masing-masing memiliki tugas dan peran sendiri sesuai dengan kompetensinya, bidan dalam urusan partus sedangkan dukun lebih ke aspek psikologis untuk menentramkan perasaan ibu bersalin. Dari kasus Ibu F di atas ternyata ia tidak mengeluarkan biaya apapun untuk persalinannya. Bidan dan dokter tidak bersedia dibayar meski mereka datang ke rumah pasien. Menurut keterangan Ibu F karena suaminya bekerja sebagai kepala Distrik Sumuri, sehingga baik bidan maupun dokter sering ditolong suami saat mereka membutuhkan surat-surat terkait kependudukan maupun urusan lainnya, sehingga mereka merasa harus saling bantu.

Periode 2010-2014 Kementrian Kesehatan melaksanakan terobosan dalam bentuk reformasi pembangunan kesehatan masyarakat. Reformasi itu dilakukan lewat tujuh upaya, salah satunya peningkatan pelayanan kesehatan di Daerah Terpencil, Perbatasan dan Kepulauan (DTPK) (Irianto 2014). Sebagai DTPK wilayah Sumuri menjadi perhatian banyak pihak, tidak hanya pemda melainkan juga pihak swasta. Penetrasi medis modern yang kuat yang dilakukan pemda dan swasta di tengah masyarakat Sumuri yang sedang membangun mengakibatkan konsep kesembuhan terhadap penyakit pun berkembang. Sehat dan sakit tidak lagi berdasar pada konsep lama melainkan telah bergeser ke konsep modern, yaitu biomedical models di mana semua penyakit dianggap berasal dari virus, kuman dan jasat renik (Galanti 2008). Proses pengobatan tidak lagi bersifat ideologis melainkan yang paling penting adalah pasien mengalami kesembuhan. Apabila dahulu proses kesembuhan dikaitkan dengan ritual keagamaan dan adat maka sekarang cenderung ke ritual medis semata. 
Mengkonsumsi jamu merupakan suatu budaya (Andriati \& Wahjudi 2016). Budaya minum jamu dapat hilang seiring dengan berubahnya perilaku konsumennya. Di Sumuri pengetahuan lokal tentang keragaman obat tradisional atau obat alami yang dikuasai oleh golongan penduduk usia tua ikut tergerus oleh banyaknya hutan yang berubah menjadi sumur gas. Akibatnya habitat tanaman lokal pun ikut hilang dan generasi yang lebih muda tidak lagi mengenal aneka tanaman obat yang menyembuhkan. Interaksi dengan alam yang panjang yang dahulu mampu menyadarkan pengetahuan mereka akan kemanjuran obat alam saat ini telah berubah seiring dengan masuknya interaksi mereka dengan orang dari luar. Interaksi dengan beragam orang dan asal yang berbeda itu membawa pengaruh pada sistem medis mereka. Unsur kearifan lokal ini seharusnya tetap dipelihara seperti yang tertulis dalam Otonomi Khusus Papua di mana dana diperuntukkan bagi peningkatan kualitas hidup dan kesejahteraan orang asli Papua (Gunawan 2008). Oleh karenanya pemerintah dewasa ini harus menyimak pengembangan daerah berbasis lokalitas sesuai aspirasi masyarakat setempat, bukan menyepelekan aspirasi masyarakat yang makin gencar dilakukan (Pekei 2014).

Pengenalan medis modern kepada masyarakat komunal, seperti di Papua Barat menuntut menggunakan berbagai macam cara. Perubahan itu bisa dilakukan lewat cara merombak cara berpikir, melihat, dan memberi contoh untuk berubah (Kasali 2007), maka keengganan masyarakat berobat ke pengobatan modern perlu dilakukan lewat bukti nyata. Seperti yang terjadi di Kabupaten Jayawijaya, masyarakat awalnya lebih suka pergi ke dukun, akan tetapi setelah tenaga medis ada yang berasal dari penduduk lokal masyarakat pun tertarik datang ke balai kesehatan untuk mengobati penyakitnya.

Di Distrik Sumuri mengingat interaksi antara penduduk lokal dan pendatang telah berlangsung lama maka pilihan ke pengobatan modern bukan disebabkan oleh faktor tenaga medis yang berasal dari penduduk lokal melainkan lebih pada aspek kesembuhan. Sembuh menjadi kata kunci bagaimana penerimaan masyarakat atas petugas kesehatan dan pelayanan kesehatan Puskesmas yang ditawarkan kepada penduduk.

Budaya masyarakat Sumuri sedang berubah. Perilaku masyarakat dalam bidang kesehatan mulai mengadopsi perilaku hidup sehat meskipun masih terbatas pada penduduk yang tingkat pendidikannya cukup tinggi serta mereka yang banyak bekerja di perusahaan minyak, gas maupun kelapa sawit yang marak di Sumuri. Introduksi tentang medis modern dikenalkan perusahaan-perusahan pertambangan maupun perkebunan lewat fasilitas pelayanan kesehatan oleh perusahaan. Ditambah lagi, keharusan tes kesehatan bagi seluruh tenaga kerjanya, kondisi ini mampu memaksa penduduk usia produktif khususnya laki-laki untuk terbiasa dengan indikator kesehatan sebagai syarat masuk kerja serta fasilitas pelayanan kesehatan modern gratis yang disediakan perusahaan tersebut. Tidak kurang peran perusahaan dalam meningkatkan akses pelayanan kesehatan tingkat tinggi bagi karyawannya. Apabila pelayanan kesehatan di perusahaan atau Puskesmas tidak mampu mengatasi penyakit yang dialami warga, maka dengan sukarela perusahaan menawarkan jasa dengan meminjamkan long boat untuk membawa pasien ke rumah sakit umum di Teluk Bintuni bahkan sampai ke Sorong. Gerak cepat perusahaan dalam membantu akses pelayanan kesehatan modern ini juga ditujukan kepada Puskesmas setempat. Apabila Puskesmas mendapatkan kasus gawat darurat yang harus secepatnya membawanya ke rumah sakit umum daerah di Bintuni maka perusahaan akan membantu long boatnya dengan cuma-cuma. Pendek kata demi menyelamatkan nyawa penduduk setempat, semua perusahaan akan bergerak cepat tanpa membutuhkan birokrasi yang berbelit-belit.

\section{Simpulan}

Masyarakat Sumuri saat ini sedang mengalami perubahan atau transisi dari medis tradisional yang dahulu tumbuh kuat ditengah masyarakat ke medis modern yang dibawa oleh pendatang, pemerintah maupun perusahaan. Pluralisme medis kuat masih dirasakan di kalangan penduduk Sumuri khususnya terkait dengan pertolongan dukun dalam pola perawatan ibu hamil maupun persalinan. Masuknya medis modern di Sumuri diterima dengan baik mengingat ada peran pemerintah, perusahaan, faktor pertumbuhan ekonomi, masuknya pendatang ke wilayah tersebut yang dengan cepat gaya hidupnya diadopsi masyarakat lokal. Dominasi medis modern mampu memarjinalkan medis tradisional. Kelemahan masuknya medis modern adalah hilangnya relasi sosial antar keluarga/kerabat. Persalinan yang biasa ditolong kerabat berubah ke tenaga kesehatan (dokter, bidan, perawat). Jika pada masa lalu 
semua persalinan berlangsung di rumah, maka sekarang berpindah ke fasilitas kesehatan (Puskesmas, Poskesdes atau rumah sakit). Medis modern dengan cepat diterima masyarakat karena sosialisasi dan peran petugas kesehatan, pemerintah maupun fasilitas pelayanan kesehatan dari perusahaanperusahaan yang beroperasi di wilayah Sumuri. Keterisolasian wilayah Sumuri teratasi lewat dominasi medis modern, sehingga pelayanan kesehatan masyarakat pedalaman dapat terwujud.

\section{Ucapan Terima Kasih}

Kepada Pusat Studi Asia Pasifik UGM melalui dana DIPA yang telah memberi kesempatan kepada penulis untuk melakukan riset di Distrik Sumuri, Teluk Bintuni, Papua Barat serta mengijinkan publikasi data ini.

\section{Daftar Pustaka}

Alesich S (2008) Dukun and Bidan: The Work of Traditional and Government Midwives in Southeast Sulawesi. In: Ford M Parker L (eds) Women and Work in Indonesia. London: Routledge.

Andriati, Wahyudi T (2016) Tingkat penerimaan penggunaan jamu sebagai alternatif penggunaan obat modern pada masyarakat ekonomi rendah-menengah-atas. Jurnal Masyarakat, Kebudayaan dan Politik 29 (3): 128-139.

Australia Indonesia Partnership for Maternal and Neonatal Health (2013) Inisiatif Dari Kabupaten. Kupang: AIPMNH.

Biro Pusat Statistik (2013) Kabupaten Teluk Bintuni Dalam Angka. BPS Teluk Bintuni

Baum F (2008) The New Public Health. Melbourne: Oxford University Press.

Burns A A, Lovich R, Maxwell J (2000) Pemberdayaan Wanita Dalam Bidang Kesehatan. Yogyakarta: Yayasan Essentia Medica.

Chongsuvivatwong V, Phua KH, Yap MT, Pocock NS, Hashim JH, Chhem R, Wilopo SA, Lopez AD (2011) Health and health care systems in southeast asia: Diversity and transitions. The Lancet 377(9763): 429-437.

Foster GM \& Anderson BG (1990) Antropologi Kesehatan. Jakarta: UI Press.

Gunawan R (2008) Luka Papua, HIV, Otonomi Khusus, dan Perang Suku. Jakarta: Spasi \& VHR Book.

Hardon A, Boonmongkon P, Streefland P, Tim ML, Hongvivatana T, van der Geest JDM, van Staa A, Varkevisser C (1995) Applied Health Research manual, Anthropology of Health and Health Care. Amsterdam: Het Spinhuis.

Irianto K (2014) Ilmu Kesehatan Masyarakat. Bandung: Alfabeta.

Irwanto (2006) Focus Group Discussion: Sebuah Pengantar Praktis. Jakarta: Yayasan Obor Indonesia.

Kasali R (2007) Re-Code Your Change DNA. Jakarta: Gramedia Pustaka Utama.

Kelompok Kerja Kesehatan Ibu dan Anak (2015) Inovasi-inovasi Dalam Program Penurunan Kematian Ibu dan Bayi. Yogyakarta: Fakultas Kedokteran UGM.

Kerthyasa TG dan Yuliani I (2013) Sehat Holistik Secara Alami: Gaya Hidup Selaras dengan Alam. Bandung: PT. Mizan Pustaka.

Kleinman A (1988) The Illness Narratives: Suffering Healing \& The Human Condition. USA: Basic Books, A Member of the Perseus Books Group.

McElroy A, Townsend P (1999) Medical Anthropology in Ecological Perspective. Colorado: Westview.

Monografi Kampung Tofoi 2013.

Pekei T (2014) Gus Dur Guru Papua. Jakarta: Suara Harapan Bangsa.

Pitoyo AJ, Yuarsi SE, Liestyaningsih U, Tamtiari W (2007) Sensus Sosial Ekonomi Kawasan DAV Teluk Bintuni 2007. Yogyakarta: Pusat Studi Kependudukan dan Kebijakan Universitas Gadjah Mada.

Rahman A, Akhmad, Kusumo H (2008) Sejarah Teluk Bintuni, Awal Pemerintahan Kolonial Belanda di Papua Hingga Terbentuknya Pemerintahan Definitif Kabupaten Teluk Bintuni Pasca Pemekaran(1898-2006). Yogyakarta: Lanarka Publisher. 
Ratnawati S, Handayani D, Rakhmawati (2013) The development of traditional herbal drink by maduranese women as an attempt to improve the health of society. Mozaik Humaniora 13(1).

Sangat HM, Zuhud EAM (2000) Kamus Penyakit dan Tumbuhan Obat Indonesia. Jakarta: Yayasan Obor Indonesia.

Survei Sosial Ekonomi Nasional 2012 (2012) Jakarta: BPS.

Warip M (2000) Etnobiologi Kawasan Mangrove. In Laksono PM (ed) Menjaga Alam Membela Masyarakat. Yogyakarta: Pusat Studi Asia Pasifik-Konphalindo-Lafadl Pustaka.

Wilopo SA (2012) Kesehatan Perempuan, Prioritas Pembangunan Abad ke 21. Yogyakarta: Pusat Kesehatan Reproduksi FK UGM.

Yuniarti F \& Verdiansyah C (2007) Ekspedisi Tanah Papua, Laporan Jurnalistik Kompas. Jakarta: Penerbit Buku Kompas. 